\title{
Imaging and scopes? It's bloody time for another branch in the decision tree
}

\author{
Virginia R. Litle, MD
}

\footnotetext{
From the Division of Thoracic Surgery, Department of Surgery, Boston University School of Medicine, Boston, Mass.

Disclosures: Author has nothing to disclose with regard to commercial support.

Received for publication Jan 20, 2018; accepted for publication Jan 30, 2018; available ahead of print Feb 23, 2018.

Address for reprints: Virginia R. Litle, MD, Division of Thoracic Surgery, Department of Surgery, Boston University, 88 E Newton St, Collamore 7380, Boston, MA 02118 (E-mail: Virginia.litle@bmc.org).

J Thorac Cardiovasc Surg 2018;155:2243-4

$0022-5223 / \$ 36.00$

Copyright (c) 2018 by The American Association for Thoracic Surgery

https://doi.org/10.1016/j.jtcvs.2018.01.056
}

So many challenges in the management of esophageal cancer persist: high perioperative morbidity for esophagectomy, poor overall survivals, and, more recently in the era of salvage esophagectomy, selection of the optimal subset after chemoradiation. Less invasive resection approaches have reduced some of the respiratory morbidity and allowed superficial tumors to be treated endoscopically, but survivals have not improved significantly, and the idea of a watch and wait approach after chemoradiation has spared some patients the esophagectomy risks. The central message of the retrospective study by Liw and colleagues ${ }^{1}$ in this issue of the Journal is that disease recurs in $50 \%$ of patients who show a complete clinical response after definitive chemoradiation for esophageal squamous cell carcinoma. This watch and wait plan needs additional direction. The literature contributions of their work are 2-fold: (1) surveillance strategies after definitive chemoradiation to identify candidates for additional treatment and (2) confirmation of clinical risk factors (stage and age) impacting disease recurrence. Their suggested surveillance protocol includes upper endoscopy every 3 months for 2 years for local recurrence and compute tomographic scan or positron emission tomographic-computed tomographic scan every 6 months for 4 years. Patients with recurrence are then offered stage-appropriate therapy. More sophisticated tests are needed to improve this algorithm for those with complete clinical response.

What are the options for improving detection of persistent gross and occult disease? Deeper biopsies on restaging and surveillance endoscopy, as suggested recently by $\mathrm{Fu}-$ jishima and colleagues ${ }^{2}$ ? Improved imaging with positron emission tomography-magnetic resonance imaging, as suggested by our nuclear medicine colleagues ${ }^{3}$ ? What about the old kid in town: blood biomarkers? For many years and for many solid tumors, investigators have detected circulating micrometastases ${ }^{4-6}$ or microsatellite instability in the serum ${ }^{7}$ and theorized a correlation with prognosis; in 2018, however, this is still not a test to be ordered through

\section{References} ahead of print].

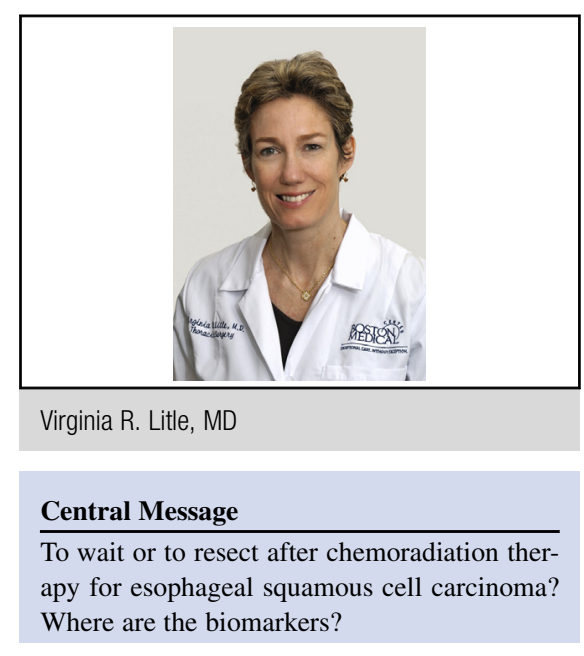

See Article page 2233.

electronic medical records. So where do we go from here? Newer investigations in our esophageal molecular research arena are potentially more promising. We have found that technical advances in digital polymerase chain reaction can improve specificity of rare event analysis ${ }^{8}$ and allow detection of circulating cell-free tumor DNA levels in the serum of patients with esophageal adenocarcinoma. In soon-to-be-published studies, these circulating cell-free tumor DNA levels have been shown to correlate with circulating response to therapy, recurrence, and disease progression, and increases in the circulating cell-free tumor DNA levels have been seen to precede radiographic evidence of changes in tumor behavior and in addition to correlate with tumor burden.

When will we draw the next branch on the decisionmaking tree for resection or no resection after chemoradiation for esophageal cancer? It may bloody well be soon.

1. Liw P-X, Wen Y-W, Tsai C-Y, Chang H-K, Tseng C-K, Hung T-M, et al Pretreatment clinical stage predicts locoregional recurrence in esophageal cancer patient who achieved a complete clinical response to chemoradiotherapy. J Thorac Cardiovasc Surg. 2018;155:2233-42.e2.

2. Fujishima F, Taniyama Y, Nakamura Y, Okamoto H, Ozawa Y, Ito K, et al. Residual carcinoma cells after chemoradiotherapy for esophageal squamous cell carcinoma patients: striving toward appropriate judgment of biopsy. Dis Esophagus. January 13, 2018 [Epub ahead of print].

3. Decazes P, Thureau S, Dubray B, Vera P. How to use PET/CT in the evaluation of response to radiotherapy. Q J Nucl Med Mol Imaging. November 28, 2017 [Epub

4. Brattström D, Wagenius G, Sandström P, Dreilich M, Bergström S, Goike H, et al Newly developed assay measuring cytokeratins 8,18 and 19 in serum is correlated 
to survival and tumor volume in patients with esophageal carcinoma. Dis Esophagus. 2005;18:298-303.

5. Nakamura T, Yasumura T, Hayashi K, Eguchi R, Ide H, Takasaki K, et al. Immunocytochemical detection of circulating esophageal carcinoma cells by immunomagnetic separation. Anticancer Res. 2000;20:4739-44.

6. Balic M, Williams A, Dandachi N, Cote RJ. Micrometastasis: detection methods and clinical importance. Cancer Biomark. 2010;9:397-419.
7. Eisenberger CF, Knoefel WT, Peiper M, Merkert P, Yekebas EF, Scheunemann P, et al. Squamous cell carcinoma of the esophagus can be detected by microsatellite analysis in tumor and serum. Clinical Cancer Res. 2003;9:4178-83.

8. Ståhlberg A, Krzyzanowski PM, Jackson JB, Egyud M, Stein L, Godfrey TE Simple, multiplexed, PCR-based barcoding of DNA enables sensitive mutation detection in liquid biopsies using sequencing. Nucleic Acids Res. 2016;44: e105. 